\title{
SOCIAL TRANSPARENCY IN RURAL AREAS IN NORWAY: PROMOTING OR RESTRAINING THE DESIRE TO STAY?
}

\author{
Maja Farstad, Alexander Zahl-Thanem ${ }^{1}$
}

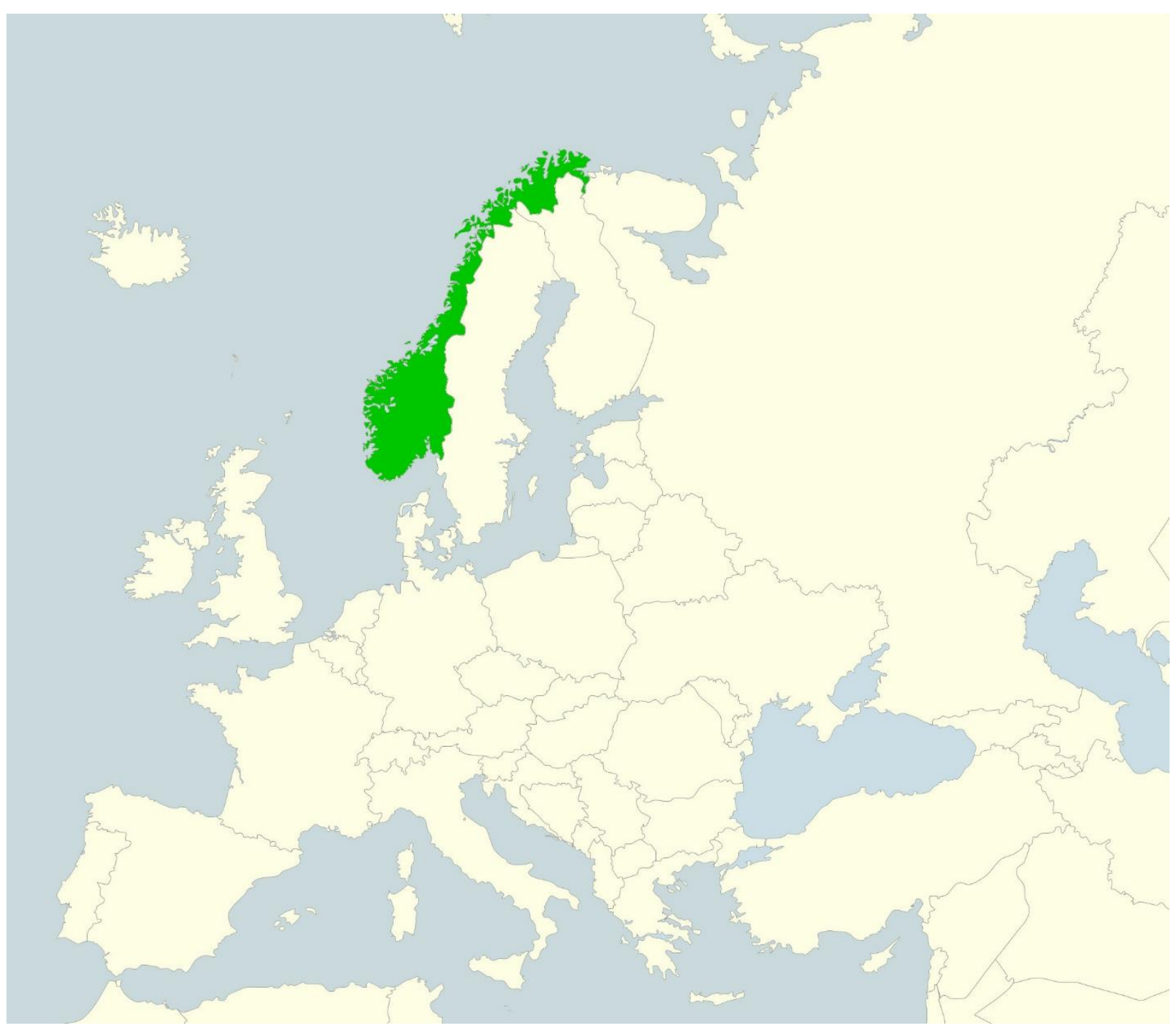

${ }^{1}$ Maja Farstad, PhD / Senior Researcher, ORCID: 0000-0002-2170-4475, maja.farstad@ruralis.no; Alexander ZahlThanem, PhD student/ Researcher, ORCID: 0000-0003-3344-2596, alexander.zahl-thanem@ruralis.no Ruralis Institute for Rural and Regional Research, Trondheim, Norway 


\begin{abstract}
Everyone knows everyone" is a recurring characteristic in descriptions of rural communities, one that has been interpreted as both a benefit and a drawback in research on such localities. In response to that discrepancy, this paper investigates the overall statistical effect of social transparency on residents' desire to continue living in their rural communities. As revealed by analyses of survey data representing a national sample of Norway's rural population in 2016, social transparency did significantly increase respondents' desire to maintain residency in their rural communities. In providing and explaining such results, the paper contributes to current understandings of social conditions that influence rural (non-)migration and rural resilience.
\end{abstract}

Key words: Social transparency; Desire to stay; Rural communities; Norway

\begin{abstract}
Sammendrag: "Alle kjenner alle" er en hyppig anvendt karakteristikk i beskrivelser av rurale samfunn, og noe som har blitt forstått både som en fordel og som en ulempe i forskningen på slike samfunn. Som en respons på denne tvetydigheten undersøker vi den overordnede statistiske effekten av sosial transparens på innbyggernes ønske om å bli boende i sine rurale lokalsamfunn. Våre analyser, basert på survey-data fra et nasjonalt utvalg av Norges rurale befolkning i 2016, indikerer at sosial transparens har en positiv effekt på innbyggernes ønske om å forbli boende i eget lokalsamfunn. Ved å frembringe og diskutere disse resultatene, komplementerer dette paperet eksisterende forståelser av samfunnsmessige forholds betydning for rural (ikke)migrasjon og rurale samfunns robusthet.
\end{abstract}

Nøkkelord: Sosial transparens; Bolyst; Rurale samfunn; Norge

\title{
Highlights:
}

- Social transparency may generate both positive and negative outcomes.

- In rural Norway, the overall outcome of transparent communities is positive.

- Increased social transparency was associated with a greater desire to stay.

- Social transparency may contribute to rural resilience.

\section{Introduction}

Both in Norway and in numerous countries worldwide, rural areas often experience challenges with out-migration, a phenomenon that researchers have attributed to a variety of complex causes (e.g. see Ritsilä and Ovaskainen 2001; Stockdale 2002). However, far from everyone emigrates, and various forms of immobility have similarly complex causes, including both aspirations and capabilities to stay and to leave (Schewel 2019). One important precondition for people not leaving rural communities is their desire to stay. The desire to stay where one lives is not only important for maintaining the rural population, but also for maintaining individuals' general wellbeing as long as they keep residing where they are. Although both material and social conditions influence the desire to maintain residency in one's community (Schewel 2019), in this paper, we focus on the latter, namely the characteristic of rural communities termed social transparency. In particular, we examine how social transparency is understood from a statistical standpoint and how it is associated with the desire to stay.

Perhaps best encapsulated in the phrase "Everyone knows everyone", social transparency is a recurring theme in both lay and scientific descriptions of rural communities. Beyond those descriptions, however, the characteristic's potential outcomes in such localities remain somewhat ambiguous. Indeed, as empirical, qualitative research has shown (Rye 2006), social transparency is recognized as a condition with both positive and negative consequences. Against that 
background, and with reference to a national survey of Norway's rural population, this paper examines the relationship between social transparency in rural areas and people's desire to continue living in their local communities. To that purpose, we formulated two research questions:

1) Statistically speaking, what are the potential positive and negative outcomes of social transparency in rural communities?

2) Does social transparency contribute to increase or decrease residents' desire to continue living in their rural communities?

Whether social transparency encourages or discourages residents' willingness to continue living in their rural communities is expected to be of international interest, for it is essential to understanding the social conditions influencing rural-to-urban migration and rural resilience.

\section{Varying conditions for social transparency in rural areas}

Rural and urban areas have traditionally been viewed as representing starkly different forms of social conventions. That trend has been reinforced not least by social scientists' frequent references to Tönnies' (2001 [1887]) concepts of Gemeinschaft and Gesellschaft, which respectively point to two types of social connections between residents in a given locality: the former based on community, the latter based on individuality. However, separating relational qualities between rural and urban areas has been complicated by important structural changes in societal development, including increased mobility, which has spurred the general growth of modern societies (Hompland 1984; Findlay et al. 2001; Almås et al. 2008; Nelson et al. 2021). In his analysis of such developments in Norway, Hompland (1984) has emphasised how the extended use of cars in rural areas has influenced forms of social life in rural communities. In particular, contemporary social networks are far less locally oriented and neighbourhood-based than before and now much more likely to be grounded in friendship, work relations, and/or mutual interests. Because rural communities seem to have become more socially fragmented, Hompland's designation of "non-local-based societies" underscores the diminished relevance of territoriality and distance. This has also been pinpointed at the international level, e.g. by Jonas (1988), arguing that "locality is a meaningful concept only in relation to the interests of individual people and not necessarily to groups of co-located people" (p. 106). Hompland has further highlighted that many neighbourhoods remain inhabited by people in somewhat equitable phases of life, albeit without a clear community-focused dimension. As such, local inhabitants in many cases may be described as living in what Hompland has called "privatized parallels". This recognition corresponds to Friedland's (1982, p. 593) description of a change to "an urban economic base and lifestyle" in small communities, more generally.

Given the overarching equalisation of modes of living in urban and rural areas that has occured, questioning whether social relations within each type of area remain qualitatively different is entirely rational. Nevertheless, at least one material condition continue to differ between rural and urban areas: By definition, rural area refers to a locality with little population density. Although having a limited number of inhabitants to relate with does necessarily involve better social oversight and some extent of social transparency, a larger number of inhabitants clearly makes such oversight and social transparency more difficult to obtain.

At the same time, rural communities also vary both in size, population density, and their distance to large urban areas. Gieryn (2000) has identified some social effects of place, all of which are influenced by both geographical localisation, the material form of the place, and the meaning and value ascribed to it. From that perspective, rural communities vary widely in their qualitative characteristics, including in terms of social atmosphere, local norms, the extent of social cohesion, and trust among inhabitants. Such variation also stems from the fact that the social dynamics in each place are necessarily influenced by the specific individuals residing there. Beyond that, qualities of each community's residential environment may be perceived differently from one person to the next, especially based upon one's current phase of life (Cloke and Little 1997; Haugen and Villa 2006a). 


\section{Social transparency: A double-edged sword?}

In reviewing literature on people's perceptions of rural areas, Rye (2006) has observed largely similar understandings of the countryside in Norway and elsewhere in Europe. Above all, rural localities are perceived as at once offering a set of positive relational qualities and a set of negative ones, all of which related to some degree of social transparency. On the one hand, they are perceived as involving strong feelings of community and a generally high degree of proximity among inhabitants. By extension, rural residents are commonly thought to care more for each other and more willingly engage in each other's lives than city dwellers (Rye 2006). Among other differences, unlike the city, the countryside is conceived as being an especially safe, wholesome environment for raising children (Halfacree 1995; Villa 1999, cited in Rye 2006; Matthews et al. 2000). For example, Valentine (1997) has observed how British parents appreciated fellow villagers who kept an eye on their children, while Jobes et al. (2005) have found that social transparency is viewed as a benefit when it comes to identifying troublemakers and solving crime in rural Australia. Furthermore, community spirit based on social transparency is assumed to generate high degrees of collective action. Altogether, the positive relational qualities stemming from the idea that "Everyone knows everyone" provide important support for the so-called "rural idyll" (Rye 2006).

On the other hand, rural areas are perceived as being characterised by strong social control, with appurtenant limitations for the individuals living there. ${ }^{2}$ Such oversight entails less tolerance for individuals who stand out, for example, by achieving success in a certain field (Rye 2006). For that reason, gossip has been reported as a major downside of social transparency (Gilmore 1978; Merry 1984; Amster 2004; Haugen and Villa 2006b). According to Valenta (2007), because places where everyone knows everyone may generate moral communities that support conformity and suppress cultural diversity, they are likely to foster xenophobia and scepticism against foreigners and, in turn, promote their social exclusion. The same phenomenon has likewise been recognised by Bell (1997).

Those drawbacks of social transparency seem to relate closely to the concepts of "the law of Jante" and "the village beast". As for the first, originally covering 10 rules serving as strict social norms in the fictional city of Jante (Sandemose 1933), "the law of Jante" has become a common term to describe certain attitudes in Norwegian society. It describes social forces that work against an individual's opportunity to excel or transcend established hierarchies, because individuals who stand out can expect to be roundly excluded or rejected by the majority (Avant and Knutsen 1993). These social forces are far from solely Norwegian; Danes, too, claim that "the law of Jante" is one of their prevailing norms (e.g., Flockhart 2005), and this cultural concept is further highly comparable to the internationally recognised "tall poppy syndrome". As for the other, "the village beast" (Brandth et al. 2013), presumably a mostly Scandinavian concept, also encapsulates various kinds of social control and sanctions against individuals who shine in one way or another. As the concept's name suggests, the phenomenon is often understood as occurring in small, transparent communities (Brandth et al. 2013).

Several scholars other than Rye (2006) have underscored the disparate sets of outcomes from social transparency. Among them, Glendinning et al. (2003) have made the same conclusion both when reviewing the literature on life for rural youth, and based on their own empirical results among rural youths in Scotland. Besser (2009) has commented upon how a small town is "the quintessential place where everyone knows everyone else, and for better or worse, monitor and sanction each other's behavior" (pp. 186, our emphasis). Added to that, in her study on immigrants' lives in northern Norway, Munkejord (2009) found that social transparency was experienced both as a strengthening and constraining factor. On the one hand, women especially thought that it facilitated their access to power, social positions, and influence. On the other, residents also cast gossip and social control as negative aspects of the same transparency (Munkejord 2009). Haugen and Villa (2006b) have likewise reported both positive appraisals that social transparency was "safe and good" - and complaints about gossip and justice in rural communities.

\footnotetext{
2 The concept of social control also relates to more positive qualities, including stability, predictability, and safety. However, in our study, we measured the downsides of that relational condition.
} 
However, to our knowledge, no studies have yet addressed how social transparency affects rural residents' desire to stay in their communities while accounting for both the positive and negative outcomes of such transparency. Thus, in this paper, we analyse data from a national survey of Norway's rural population regarding perceptions of social transparency and its effects in rural locales. In the following section, we describe our data and methods used in the study before presenting the major results of our analyses. Next, we discuss those results in light of previous research and theory, after which we consider the potential implications of our findings and suggest directions for further research.

\section{Methodology}

The study for this paper used data from a national survey of Norway's rural population (The Norwegian Local Communities Survey) aimed at mapping how residents are situated where they live, in terms of both living conditions and their subjective experiences. A random sample of residents, living in what we defined as the rural municipalities of Norway, was drawn from Norway's Central Population Register and distributed to 3500 inhabitants. The classification of rural municipalities was based on three characteristics: centrality, population density, and economic structure. To qualify as rural, a municipality had to meet at least one of the following criteria: a) be more than a 45 -minutes by car from an urban centre, b) have more than $50 \%$ of its residents live in sparsely populated areas, and c) have more than $6 \%$ of its workforce employed in primary industries (Storstad 2012). In Norway, 64\% of municipalities are classified as rural, and $19 \%$ of the population lives in rural municipalities (Zahl-Thanem and Haugen 2019). Among the 3500 recipients, 1093 respondents completed and returned the questionnaire, which yields a response rate of $31.2 \%$. Due to missing responses to various questions, the number of respondents included in our analyses was reduced to 868 respondents ${ }^{3}$. Although we find the mean age and educational level in the survey to deviate somewhat compared to official data on the population, we consider the survey to be largely representative of the Norwegian rural population ${ }^{4}$.

Using bivariate correlations and multiple regression analyses with ordinary least squares (OLS) in Stata 16, we examined the outcomes of social transparency in relation to residents' perceptions of their communities, including respondents' desire to continue living in their rural communities. In the following sections, we outline the measures and statistical analyses applied in this paper.

\section{Statistical analyses}

To examine the different outcomes from social transparency in rural areas, several variables were included in the analyses based on previous research and theory. First, we conducted a correlation matrix to examine the bivariate correlations between social transparency, desire to stay in the local community, and a set of statements concerning the respondents' local community. Second, we conducted a multiple regression analysis (OLS) predicting the effect of social transparency on the respondents' desire to stay in the local community after adjusting for different demographic and social-economic variables. The descriptive statistics for all variables appear in Table 1.

Desire to stay. In the survey, respondents were asked to what degree they agreed or disagreed with a set of statements about their community: "I strongly identify with this place", "I couldn't imagine living anywhere else", and "I feel that I have more in common with people living elsewhere than those living where I live". Responses to those statements were measured on a Likert scale ranging from 1 (strongly disagree) to 5 (strongly agree). Respondents' mean score on these three

\footnotetext{
3 The missing values are not caused by issues related to any specific variable, these are rather a result of listwise deletion. We found no systematic pattern in the missing values.

${ }^{4}$ Comparing the survey with population data shows only insignificant gender differences (survey: $48 \%$ females, population: $49 \%$ females), and a small deviation in mean age (survey: 55y, population: $51 \mathrm{y}$ ). Individuals with higher education are somewhat overrepresented in our sample (survey: 34\%, population: $21 \%$ ). Thus, educational level and age were included as control variables in our main analyses (Population data is gathered from the platform www.Microdata.no).
} 
items yielded a summary measure of what we termed desire to stay (Cronbach's alpha $=.73$ ), which was treated as a continuous variable in our analyses ${ }^{5}$. A higher score indicated a greater desire to continue living in the community, whereas a lower one indicated a lower desire to do so. Surveys with missing values for one or more of the statements were excluded from being measured for desire to stay.

Despite established terms and measures related to desire to stay - for instance, "community satisfaction", "community attachment", and "community integration" - we deemed it necessary to create a new variable 6 . Whereas our variable covers only (relevant dimensions of) the emotional desire to live and continue living in one's community, the other measures include both sentimental connections and more practical or action-oriented aspects of an individual's attachment to a particular place (Marquart-Pyatt and Petrzelka 2008, p. 257).

Everyone knows everyone (EKE). As a subjective indicator of the degree of social transparency in respondents' communities, everyone knows everyone (EKE) was measured by their responses to the question, "Reflecting on your community, how much do you agree or disagree with the following statement: 'Broadly speaking, everyone knows everyone'"? Responses were given on a Likert scale ranging from 1 (strongly disagree) to 5 (strongly agree), and EKE was thus treated as a continuous variable.

Statements about place. Respondents were asked to what degree they agreed or disagreed with a set of six statements concerning their respective communities. The selection of variables was based on previous research as well as available data and marked an attempt to create a reasonable balance between positive and negative attributes represented by the statements: "People who live here care in a positive way", "People who live here can trust each other", "There is a community spirit that facilitates collective action", "There are clear rules for what is acceptable behaviour in my community", "There is too much gossip where I live", and "It is difficult to get to know people who live here". All statements were measured on a Likert scale ranging from 1 (strongly disagree) to 5 (strongly agree) and thus treated as continuous variables.

Demographic and socioeconomic control-variables. Age was recorded into three dummy variables, with age of 60 years or older used as a reference category. By contrast, gender was coded as a dummy variable, with women coded as 1 and men as 0 . Level of education measured the respondents' respective level of education, wherein university education was coded as 1 , and degrees at lower levels as 0 . Next, gross income was coded in 11 categories that measured the respondents' total income from 1 ("Below 100,000 Norwegian kroner" or approx. EUR 10,000) to 11 ("Over 1,000,000 Norwegian kroner" or approx. EUR 100,000) and was thus treated as a continuous variable measuring a linear increase or decrease in gross income.

Respondents labelled as with children under 18 years old were assigned the value 1, whereas ones labelled without children under 18 years old were assigned the value 0 . Raised in the community was a dummy variable based on the question, "Were you raised in the community where you now live?" Respondents who were raised in their current communities were coded as 1 , whereas those who were not were coded as 0 . Added to that, living in the community $\geq 10$ years was another dummy variable identifying respondents who had lived in their current communities for at least 10 years, all coded as 1 , whereas respondents who had lived in the community for less than 10 years were coded as 0 . Last, friends in the community was yet another dummy variable measuring respondents' social bonds. Respondents who reported having "Some" or "Many" friends were coded as 1, whereas those with "Few" friends or "None" were coded as 0.

\footnotetext{
${ }^{5}$ The third item was reverse-ordered to construct an internally consistent scale measuring desire to stay.

${ }^{6}$ While "I couldn't imagine living anywhere else" appears to be the strongest indicator of the desire to stay, a dependent variable composed of an index ensures that potential sources of error get evened out and, hence, it provides a more reliable measure of the phenomenon. This happens because indexes collect different, but related information of the same phenomenon, which increases the precision of the concept (e.g. Jackson and Milliron 1986; Hellevik 2006).
} 
Tab 1. Descriptive statistics of the study's variables among rural respondents. Source: The Norwegian Local Communities Survey 2016

\begin{tabular}{|c|c|c|c|c|c|}
\hline & $N$ & Mean & $S D$ & Min. & Max. \\
\hline Desire to stay $(1=$ low, $5=$ high $)$ & 868 & 3.101 & 0.633 & 1 & 5 \\
\hline $\begin{array}{l}\text { Everyone knows everyone (EKE) } \\
\text { ( } 1=\text { strongly disagree, } 5=\text { strongly agree) }\end{array}$ & 868 & 3.901 & 1.070 & 1 & 5 \\
\hline \multicolumn{6}{|l|}{$\begin{array}{l}\text { Statements about place } \\
(1=\text { strongly disagree, } 5=\text { strongly agree })\end{array}$} \\
\hline People who live here care in a positive way & 868 & 3.720 & 0.947 & 1 & 5 \\
\hline People who live here can trust each other & 868 & 3.720 & 0.926 & 1 & 5 \\
\hline $\begin{array}{l}\text { There is a community spirit that facilitates collective } \\
\text { Action }\end{array}$ & 868 & 3.515 & 1.049 & 1 & 5 \\
\hline $\begin{array}{l}\text { There are clear rules for what is acceptable } \\
\text { behaviour in my community }\end{array}$ & 868 & 2.702 & 1.127 & 1 & 5 \\
\hline There is too much gossip where I live & 868 & 2.685 & 1.061 & 1 & 5 \\
\hline It is difficult to get to know people who live here & 868 & 2.455 & 1.124 & 1 & 5 \\
\hline \multicolumn{6}{|l|}{ Demographic variables } \\
\hline Gender (woman=1, man=0) & 868 & 0.518 & 0.500 & 0 & 1 \\
\hline Age categories & 868 & & & & \\
\hline Age $18-40$ & & 0.207 & 0.406 & 0 & 1 \\
\hline Age $40-59$ & & 0.408 & 0.492 & 0 & 1 \\
\hline Age $60+$ & & 0.385 & 0.487 & 0 & 1 \\
\hline Level of education: university education (yes $=1$, no $=0$ ) & 868 & 0.364 & 0.481 & 0 & 1 \\
\hline Gross income (1=low, 11=high) & 868 & 4.645 & 2.097 & 1 & 11 \\
\hline With children under 18 years old (yes=1, no=0) & 868 & 0.276 & 0.448 & 0 & 1 \\
\hline Raised in the community (yes $=1, \mathrm{no}=0$ ) & 868 & 0.524 & 0.500 & 0 & 1 \\
\hline Living in the community $\geq 10$ years $(y e s=1$, no $=0$ ) & 868 & 0.833 & 0.373 & 0 & 1 \\
\hline Friends in the community (yes $=1, \mathrm{no}=0$ ) & 868 & 0.711 & 0.454 & 0 & 1 \\
\hline
\end{tabular}

\section{Results}

The descriptive statistics in Table 1 show that rural respondents' desire to continue living in their communities on average was centred at the middle of the 5-point scale (i.e., 3.1), thereby indicating that the respondents' desire to remain in their rural communities, at least on average, was somewhat middling. Among other results, what may be called "positively loaded" statements about community - about people caring for each other, trusting each other, and having community spirit - achieved higher mean scores than their negative counterparts - that is, about social rules, gossip, and social barriers - thus indicating that respondents to a greater extent agreed with the positively loaded community statements than the negatively loaded ones. ${ }^{7}$

Table 2 shows the distribution of perceived social transparency in respondents' communities, measured by the statement concerning their communities and whether they agree or disagree that, broadly speaking, everyone knows everyone there. Two-thirds of the respondents agreed with the statement, whereas a fourth neither agreed nor disagreed, and $12 \%$ disagreed. Although a large share of respondents reported living in socially transparent communities, the distribution reflects large variations in the degrees of perceived social transparency within the rural communities that respondents represented.

\footnotetext{
${ }^{7}$ Differences were confirmed by supplementary t tests, whose results are available upon request.
} 
Tab 2. Rural residents' ( $n=868$ ) responses to the statement "Broadly speaking, everyone knows everyone" in their rural communities. Source: The Norwegian Local Communities Survey 2016

\begin{tabular}{|l|r|}
\hline & Percentages \\
\hline Strongly agree & $35 \%$ \\
\hline Somewhat agree & $36 \%$ \\
\hline Neither agree nor disagree & $18 \%$ \\
\hline Somewhat disagree & $8 \%$ \\
\hline Strongly disagree & $4 \%$ \\
\hline Total & $100 \%$ \\
\hline
\end{tabular}

Table 3 shows the bivariate correlations between the study's variables, including the ones measuring social transparency (i.e. EKE), respondents' desire to continue living in their communities, and their responses to items concerning their community. Bivariate analysis revealed a positive correlation between EKE and the respondents' desire to remain in their communities, as well as between EKE and the items "People who live here care in a positive way", "People who live here can trust each other", and "There is a community spirit that facilitates collective action". However, EKE did not significantly correlate with the items "There are clear rules for what is acceptable behaviour in my community" or "There is too much gossip where I live". By further contrast, EKE negatively correlated with the item "It is difficult to get to know people who live here", which suggests that it may be easier to familiarise oneself with other members of the community if, broadly speaking, "Everyone knows everyone".

Tab 3. Bivariate correlations between the study's variables. Source: The Norwegian Local Communities Survey 2016

\begin{tabular}{|c|c|c|c|c|c|c|c|c|}
\hline & 1 & 2 & 3 & 4 & 5 & 6 & 7 & 8 \\
\hline 1. Desire to stay in the community & 1 & & & & & & & \\
\hline 2. Everyone knows everyone (EKE) & $0.20^{\star \star}$ & 1 & & & & & & \\
\hline $\begin{array}{l}\text { 3. People who live here care in a positive } \\
\text { way }\end{array}$ & $0.34^{* *}$ & $0.26^{* *}$ & 1 & & & & & \\
\hline $\begin{array}{l}\text { 4. People who live here can trust each } \\
\text { other }\end{array}$ & $0.24^{* *}$ & $0.31^{* *}$ & $0.54^{\star *}$ & 1 & & & & \\
\hline $\begin{array}{l}\text { 5. There is a community spirit that } \\
\text { facilitates collective action }\end{array}$ & $0.19^{* *}$ & $0.32^{* *}$ & $0.42^{* *}$ & $0.40^{\star *}$ & 1 & & & \\
\hline $\begin{array}{l}\text { 6. There are clear rules for what is } \\
\text { acceptable behaviour in my community }\end{array}$ & 0.02 & 0.02 & $-0^{*} 1^{* *}$ & $0.20^{\star \star}$ & $-0.07^{*}$ & 1 & & \\
\hline 7. There is too much gossip where I live & -0.04 & 0.02 & $-\overline{0.34^{* *}}$ & $-\overline{0.39 * *}$ & $-\overline{0.13^{\star *}}$ & $0.27^{\star \star}$ & 1 & \\
\hline $\begin{array}{l}\text { 8. It is difficult to get to know people who } \\
\text { live here }\end{array}$ & $-0.08^{*}$ & $-0^{*}$ & $0.40^{\star *}$ & $-0^{-} 36^{\star *}$ & $0.21^{* *}$ & $0.24^{\star *}$ & $0.32^{* \star}$ & 1 \\
\hline
\end{tabular}

Pearson correlation ( $r)$.

${ }^{*} \mathrm{P}<0.05,{ }^{* *} \mathrm{P}<0.01$. ( $\left.n=868\right)$.

As with EKE, respondents' desire to continue living in their rural communities positively correlated with the items "People who live here care in a positive way", "People who live here can trust each other", and "There is a community spirit that facilitates collective action". Added to that, their desire to remain in their communities negatively correlated with the item "It is difficult to get to know people who live here" and did not significantly correlate with the items "There is too much gossip where I live" or "There are clear rules for what is acceptable behaviour in my community".

Although the correlation matrix revealed a significant correlation between respondents' desire to continue living in their rural communities and social transparency (i.e. EKE), we needed to perform 
a multiple regression analysis in order to adjust for the effects of sociodemographic variables and to identify potential spurious effects. Table 4 lists the results of the block-wise OLS-regression analysis, in which the dependent variable was respondents' desire to continue living in their communities. In the analysis, Model 1 represented a bivariate correlation between EKE and desire to remain in one's community, whereas Model 2 represented their correlation after adjusting to several independent sociodemographic variables. Producing results from two models enabled analysing EKE's independent effect on desire to remain in the community and whether that effect ceased after we included the variables in Model 2. A positive coefficient indicated that an increase in the independent variable prompted another increase in the dependent variable, whereas a negative coefficient indicated that an increase in the independent variable prompted a decrease in the dependent variable.

Tab 4. Block-wise ordinary least squares regression analysis of rural residents' desire to stay in their communities. Source: The Norwegian Local Communities Survey 2016

\begin{tabular}{|c|c|c|}
\hline Independent variables: & $\begin{array}{l}\text { Model } 1 . \\
\text { Coeff. (SE) }\end{array}$ & $\begin{array}{l}\text { Model } 2 . \\
\text { Coeff. (SE) }\end{array}$ \\
\hline $\begin{array}{l}\text { Everyone knows everyone ( } 1=\text { strongly disagree, } 5=\text { strongly } \\
\text { agree) }\end{array}$ & $\begin{array}{l}0.118^{\star *} \\
(0.020) \\
\end{array}$ & $\begin{array}{l}0.084^{\star *} \\
(0.019) \\
\end{array}$ \\
\hline Gender (woman $=1, \operatorname{man}=0)$ & & $\begin{array}{l}-0.036 \\
(0.043) \\
\end{array}$ \\
\hline \multicolumn{3}{|l|}{ Age dummies (Age $60+$ as reference) } \\
\hline Age 18-39 & & $\begin{array}{l}-0.169^{\star *} \\
(0.064)\end{array}$ \\
\hline Age $40-59$ & & $\begin{array}{l}-0.164^{\star \star} \\
(0.051)\end{array}$ \\
\hline \multicolumn{2}{|l|}{ Level of education: university education (yes $=1, \mathrm{no}=0$ ) } & \begin{tabular}{|l}
0.029 \\
$(0.045)$ \\
\end{tabular} \\
\hline Gross income (1=low, 11=high) & & $\begin{array}{l}-0.008 \\
(0.011)\end{array}$ \\
\hline With children under 18 years old (yes $=1$, no $=0$ ) & & $\begin{array}{l}0.067 \\
(0.051)\end{array}$ \\
\hline Raised in the community (yes $=1, \mathrm{no}=0$ ) & & $\begin{array}{l}0.286^{\star *} \\
(0.047)\end{array}$ \\
\hline Living in the community $>10$ years $($ yes $=1$, no $=0$ ) & & $\begin{array}{l}0.166^{*} \\
(0.065) \\
\end{array}$ \\
\hline \multicolumn{2}{|l|}{ Friends in the community (many or some $=1$, none or few $=0$ ) } & $\begin{array}{l}0.113^{\star} \\
(0.047)\end{array}$ \\
\hline Constant & $\begin{array}{l}2.642^{* *} \\
(0.080) \\
\end{array}$ & $\begin{array}{l}2.220^{*} \\
(0.120) \\
\end{array}$ \\
\hline$R^{2}$ & 0.04 & 0.16 \\
\hline$n=868$ & & \\
\hline
\end{tabular}

Model 1 captured a positive correlation between EKE and desire to stay, thereby revealing that an increase in respondents' perception that everyone knows everyone in the community was associated with a greater desire to continue living in that community. The $R^{2}$ value indicated that EKE alone explained approximately $4 \%$ of the variation in respondents' desire to remain in their communities. EKE's effect was also statistically significant after we adjusted to the effect of all of 
the independent variables in Model 2. Including the variables increased $R^{2}$, meaning that the variables in Model 2 explained approximately $16 \%$ of the variation in respondents' desire to stay.

Our analyses additionally revealed that respondents aged 18-39 and 40-59 years both expressed significantly less desire to continue living in their rural communities than the ones over 60 years old. Respondents raised in their current communities indicated a significantly greater desire to continue living in those communities than respondents who were not raised there. Moreover, respondents who had lived in their communities for more than 10 years reported a significantly greater desire to continue living there than respondents who had lived in their communities for less than 10 years. Lastly, respondents with some or many friends in their communities expressed a significantly greater desire to remain in those communities. Gender, level of education, income, and having or not having children under 18 years of age did not significantly affect respondents' desire to remain in their communities.

\section{Discussion}

This paper contributes to current understandings about social transparency's different outcomes in rural areas and about its potential encouraging or discouraging effects on desire to continue living in those areas. Although research has shown that socially transparent communities can represent a double-edged sword, wherein social transparency may generate both positive and negative outcomes, our results suggest that the overall outcome of socially transparent communities is positive.

By analysing survey data from a national sample of Norway's rural population, we found that social transparency correlated with several positive community-related attributes (i.e., trust, caring for others, and collective action), whereas correlations between social transparency and negative outcomes, including social control and gossip, did not correlate significantly. Those findings do not imply, however, that gossip and social control do not occur in rural communities; on the contrary, it seems that gossip and social control may occur in both transparent and nontransparent rural communities. Farstad's (2016) study has confirmed that incriminating gossip is a principally rural phenomenon, one reported by $22 \%$ of respondents living in Norway's most peripheral areas compared with only $4 \%$ of respondents dwelling in Norway's large cities. Nevertheless, our results imply that such negative attributes are generally less common than positive ones in rural transparent societies (Table 1).

Among our major findings, increased social transparency was associated with a greater desire to continue living in one's rural community, whereas less social transparency was associated with less of a desire to do so. The positive correlation between social transparency and desire to stay aligned with our expectations, especially after we observed in bivariate analyses that social transparency did not correlate positively with any of the items addressing negative communityrelated aspects. Drawing from those results, we propose that socially transparent rural communities may partly prevent out-migration from rural communities and contribute to rural resilience, particularly following other results showing that relational and social factors are also important for people's mental health and wellbeing (e.g., Sirgy and Cornwell 2002; MatarritaCascante 2010). Socially transparent communities where everyone knows everyone may generally maintain higher levels of social cohesion, social bonds, friendships, and a general attachment to one's community, all of which positively contribute to individual wellbeing and a greater desire to continue living in such communities. That being said, what characterises a socalled "good community" remains elusive. Whereas some people appreciate localities with robust social oversight and close social bonds, others may prefer as little social involvement and as much anonymity as possible where they live. Still, others may not want to be engaged whatsoever in the relational aspects of their community. Thus, although one's community somewhat affects how much he or she thrives there, it is moreover a question of subjective perceptions and preferences.

On the whole, our results imply that rural areas should not undervalue the importance of arranging for and pursuing stronger social integration and cohesion, because social transparency contributes positively to residents' desire to continue living in such areas. Some societies are too 
crowded to expect that everyone will know everyone; nevertheless, that relational quality may be achieved in smaller parts of the larger society. Other societies, by contrast, may be moderately crowded to the extent that it would be difficult to prevent the phenomenon of everyone knowing everyone else, if social transparency appeared to have a discouraging effect on residents' desire to continue living in those areas. Our results do not give rise to special concern for those societies, however. Even so, the quality of local, social relationships may often benefit from further improvements, anyhow.

Our findings regarding social transparency and desire to stay in one's rural community stress more than such transparency's negative outcomes (e.g., gossip and strict norms) sometimes highlighted in relation to small, socially transparent places in lay discourses and media. As such, our results may partly prevent negative representations of social transparency from colouring the dominant narrative of social life in rural communities.

Along with social transparency, the variables of age, having been raised in one's current community, having lived in that community for more than 10 years, and having friends there also exerted a statistically positive effect on people's desire to continue living in their communities. Having some or many friends in one's community clearly boosted the desire to stay there, and the positive influence of having been raised in the community and having lived there for more than 10 years aligns with past results indicating that the length of stay in a community is crucial for significant attachment to, satisfaction with, and integration into one's community (cf. MarquartPyatt and Petrzelka 2008). As with the effect of having or not having friends in one's community, those results seem to be rational, for current conditions imply that a sufficiently long length of stay is necessary to become thoroughly socially integrated. At the same time, the relationship is potentially one questioning which came first, the chicken or the egg, because residents may have ended up living in their communities for such a long time precisely because of their desire to stay there. From another angle, age's positive statistical effect on desire to stay aligned remarkably well with past research (Haugen and Villa 2006a), which has suggested that younger people more often perceive the negative outcomes of social transparency. However, advancing through the various age groups, the significant difference between younger and older respondents did not emerge until the group of people aged 60 years or older came into play, which indicates that younger people's desire to stay is mostly the same as that of for middle-aged individuals.

The idea that "Everyone knows everyone" in a rural community and the desire to continue living there are both subjective indicators and, as such, typically studied using qualitative approaches. Although qualitative approaches contribute to in-depth understandings of residents' perceptions and thoughts, quantitative approaches can complement qualitative studies by affording the possibility of analysing a variety of patterns and associations among larger samples of rural residents. Such strengths also applied in our study, which was based on a large national sample of a rural population and, for that reason, was quite unique. After all, rural residents are often corralled into a sub-group in most national surveys. Nevertheless, applying quantitative approaches to such subjective phenomena also entailed some limitations that warrant consideration.

For one, the item measuring social transparency in our study - that is, "Everyone knows everyone" - was subject to individual perceptions. As Burnett (1996) has underscored, that concept cannot be accurate according to the empirical reality, for even in places with the strongest social cohesion, it is unlikely that everyone knows everyone else equally, and some individuals may not be socially integrated to the same extent as others. However, we argue that every resident, regardless of his or her social situation, could at least have a certain perception of the general degree of social transparency in their community. Furthermore, responses to the EKE item were requested by presenting a scale ranging from 1 to 5 , and the opportunity to report different degrees of the phenomenon in the survey probably encouraged respondents to thoroughly consider the actual situation in their own communities.

An important aspect of our results is that they stem from analyses that included responses from across rural Norway, and, as such, they reflect general trends and patterns. As mentioned earlier, rural communities vary widely in terms of qualitative characteristics such as social atmosphere, peculiar norms, extent of social cohesion, and extent of trust between inhabitants. Thus, 
the distribution of social transparency's positive and negative outcomes is likely highly specific to place, and for that reason, community-individual results could be expected to indicate trends other than what our results show. However, for potential future comparisons with other countries, such general trends and patterns at the national level will be most relevant.

The level at which our study was undertaken also seems to have affected the discrepancy between our results and findings from other qualitative research, such as Haugen and Villa's (2006a), which suggest that younger people, especially women, more strongly perceive social transparency's negative aspects than other members of the community. However, we did not detect any significant difference between men and women regarding their desire to continue living in their communities. Although qualitative research, by virtue of its more probing investigations, has often revealed and emphasised social mechanisms and explanations at the micro-scale, our study indicates that the previously identified link between social transparency's negative outcomes and young women should not be generalised to the national scale.

\section{Conclusion}

Research, both in Norway and internationally, has shown that social transparency represents both positive and negative relational qualities in rural communities, and this double-edged sword thus encouraged us to statistically examine the nature and consequences of social transparency. In particular, we investigated social transparency's potential positive and negative outcomes and whether such transparency increases or decreases residents' desire to continue living in their rural communities. Using a large-scale national survey of Norway's rural population, we found that social transparency correlates positively with a set of positive outcomes and represents a factor that may heighten rural residents' desire to continue living in their communities. Although social control, gossip, and social exclusion exist in both transparent and less transparent communities, our results suggest that increased levels of social transparency do not statistically correlate with increased levels of social control, gossip, or social exclusion. On the contrary, it may partly prevent out-migration from rural communities and contribute to rural resilience.

By extension, our findings underscore that social conditions should be taken into account and promoted, along with more traditional attributes of resilience such as the labour market and accessible housing. In that light, it would be unsurprising if the different attributes somewhat mutually influence each other. As long as the settlement of rural areas persists, and provided that rural areas remain rural, social transparency will continue to affect their resilience, particularly due to the social oversight that dispersed settlement allows. Although social transparency generally seems to be beneficial to rural communities in Norway, it would be interesting to know whether its downsides exert greater influence upon residents' desire to stay in their communities in other countries.

\section{Acknowledgement}

The authors are grateful to two anonymous reviewers for helpful comments on a previous version of this paper. The research was financed by Ruralis and the strategic institute priority project "Rural communities between resilience and vulnerability".

Academic references

[1] Almås, R., Haugen, M. S., Rye, J. F. \& Villa, M. (2008). Omstridde bygder. In Almås, R., Haugen, M. S., Rye, J. F. \& Villa, M., eds., Den nye bygda (pp. 11-28). Trondheim: Tapir Akademisk Forlag.

[2] Amster, M. H. (2004). The "many mouths" of community: Gossip and social interaction among the Kelabit of Borneo. Asian Anthropology 3(1), 97-127. DOI: 10.1080/1683478X.2004.10552544. 
[3] Avant, G. \& Knutsen, K. (1993). Understanding cultural differences: Janteloven and social conformity in Norway. ETC: A Review of General Semantics 50(4), 449-460.

[4] Bell, D. (1997). Anti-idyll: rural horror. In Cloke, P. \& Little, J., eds., Contested countryside cultures: otherness, marginalisation, and rurality (pp. 94-108). London: Routledge.

[5] Besser, T. I. (2009). Changes in small town social capital and civic engagement. Journal of Rural Studies 25(2), 185-193. DOI:10.1016/j.jrurstud.2008.10.005.

[6] Brandth, B., Haugen, M. S. \& Kramvig, B. (2013). Taming the village beast: rural entrepreneurship as the art of balance between economic growth and social sustainability. In Figueiredo, E. \& Raschi, A., eds., Fertile links? Connections between tourism activities, socioeconomic contexts and local development in European rural areas (pp. 107-127). Firenze: Firenze University Press.

[7] Burnett, K. A. (1996). Once an incomer, always an incomer? In Chapman, P. \& Lloyd, S., eds., Women and access in rural areas. What makes the difference? What difference does it make? (pp. 18-31). Aldershot: Avebury.

[8] Cloke, P. \& Little, J. (1997). Conclusion: marginality and rural others. In Cloke, P. \& Little, J., eds., Contested countryside cultures: otherness, marginalisation, and rurality (pp. 272-285). London: Routledge.

[9] Farstad, M. (2016). Relasjonelle kvaliteter i bygd og by: Stereotypene møter innbyggernes erfaringer. In Villa, M. \& Haugen, M. S., eds., Lokalsamfunn (pp. 260-282). Oslo: Cappelen Damm Akademisk.

[10] Findlay, A. M., Stockdale, A. Findlay, A. \& Short, D. (2001). Mobility as a driver of change in rural Britain: an analysis of the links between migration, commuting and travel to shop patterns. International Journal of Population Geography 7, 1-15. DOI: 10.1002/ijpg.201.

[11] Flockhart, T. (2005). Critical junctures and social identity theory: explaining the gap between Danish mass and elite attitudes to Europeanization. Journal of Common Market Studies 2005(2), 251-271. DOI: 10.1111/j.0021-9886.2005.00554.x.

[12] Friedland, W. H. (1982). The end of rural society and the future of rural sociology. Rural Sociology 47(4), 589-608.

[13] Gieryn, T. F. (2000). A space for place in sociology. Annual Review of Sociology 26, 463496. DOI: 10.1146/annurev.soc.26.1.463.

[14] Gilmore, D. (1978). Varieties of gossip in a Spanish rural community. Ethnology 17(1), 8999. DOI: $10.2307 / 3773282$.

[15] Glendinning, A., Nuttall, M., Hendry, L., Kloep, M. \& Wood, S (2003). Rural communities and well-being: a good place to grow up? The Sociological Review 51(1), 129-156. DOI: 10.1111/1467-954X.00411.

[16] Halfacree, K. (1995). Talking about rurality: social representations of the rural as expressed by residents of six English parishes. Journal of Rural Studies 11(1), 1-20. DOI: 10.1016/0743-0167(94)00039-C.

[17] Haugen, M. S. \& Villa, M. (2006a). Rural idylls or boring places? In Bock, B. B \& Shortall, S., eds., Rural gender relations: issues and case studies (pp. 181-195). Wallingford: CABI Publishing.

[18] Haugen, M. S. \& Villa, M. (2006b). Big brother in rural societies: Youths' discourses on gossip. Norsk Geografisk Tidsskrift - Norwegian Journal of Geography, 60(3), 209-216. DOI: 10.1080/00291950600889996.

[19] Hellevik, O. (2006). Forskningsmetode i sosiologi og statsvitenskap. Oslo: Universitetsforlaget.

[20] Hompland, A. (1984). Rurbaniseringsprosessen: bygdebyen og det nye Norges ansikt [Working paper no. 9/84]. Oslo: Institutt for samfunnsforskning. 
[21] Jackson, B. R. \& Milliron, V. C. (1986). Tax compliance research: findings, problems, and prospects. Journal of Accounting Literature 5, 125-166.

[22] Jobes, P. C., Donnermeyer, J. F. \& Barclay, E. (2005). A tale of two towns: social structure, integration and crime in rural New South Wales. Sociologia Ruralis 45(3), 224-244. DOI: 10.1111/j.1467-9523.2005.00302.x.

[23] Jonas, A. (1988). A new regional geography of localities? Area 20(2), 101-110.

[24] Marquart-Pyatt, S. T. \& Petrzelka, P. (2008). Trust, the democratic process, and involvement in a rural community. Rural Sociology 73(2), 250-274. DOI: 10.1526/003601108784514598.

[25] Matarrita-Cascante, D. (2010). Changing communities, community satisfaction, and quality of life: a view of multiple perceived indicators. Social Indicators Research 98, 105-127. DOI: $10.1007 / s 11205-009-9520-z$.

[26] Matthews, H., Taylor, M., Sherwood, K., Tucker, F. \& Limb, M. (2000). Growing-up in the countryside: children and the rural idyll. Journal of Rural Studies 16(2), 141-153. DOI: 10.1016/S0743-0167(99)00059-5.

[27] Merry, S. E. (1984). Rethinking gossip and scandal. In Black, D., ed., Toward a general theory of social control (pp. 271-302). New York: Academic Press.

[28] Munkejord, M. C. (2009). Hjemme i nord. En analyse av stedsopplevelser med utgangspunkt i kvinnelige og mannlige innflytteres fortellinger om hverdagsliv i Havøysund og Vadsø, Finnmark [PhD thesis]. Tromsø: Universitetet i Tromsø.

[29] Nelson, K. S., Nguyen, T. D., Brownstein, N. A., Garcia, D., Walker, H. C., Watson, J. T. \& Xin, A. (2021). Definitions, measures, and uses of rurality: A systematic review of the empirical and quantitative literature. Journal of Rural Studies 82, 351-365. DOI: 10.1016/j.jrurstud.2021.01.035.

[30] Ritsilä, J. \& Ovaskainen, M. (2001). Migration and regional centralization of human capital. Applied Economics 33(3), 317-325. DOI: 10.1080/00036840122485.

[31] Rye, J. F. (2006). Rural youths' images of the rural. Journal of Rural Studies 22(4), 409-421. DOI: 10.1016/j.jrurstud.2006.01.005.

[32] Schewel, K. (2019). Understanding immobility: moving beyond the mobility bias in migration studies. International Migration Review 54(2), 328-355. DOI: 10.1177/0197918319831952.

[33] Sirgy, M. J. \& Cornwell, T. (2002). How neighborhood features affect quality of life. Social Indicators Research 59, 79-114. DOI: 10.1023/A:1016021108513.

[34] Stockdale, A. (2002). Towards a typology of out-migration from peripheral areas: a Scottish case study. International Journal of Population Geography 8(5), 345-364. DOI: 10.1002/ijpg.265.

[35] Storstad, O. (2012). På vei mot et norsk bygdebarometer [Research report 11/2012]. Trondheim: Norsk senter for bygdeforskning.

[36] Tönnies, F. (2001) [1887]. Community and civil society. Cambridge: Cambridge University Press.

[37] Valenta, M. (2007). Daily life and social integration of immigrants in city and small town evidence from Norway. International Journal on Multicultural Societies (IJMS) 9(2), 284-306.

[38] Valentine, G. (1997). A safe place to grow up? Parenting, perceptions of children's safety and the rural idyll. Journal of Rural Studies 13(2), 137-248. DOI: 10.1016/S07430167(97)83094-X.

[39] Villa, M. (1999). Rural life courses in Norway: living within the rural-urban complementary. History of the Family 5(4), 473-490. DOI: 10.1016/S1081-602X(00)00056-7.

[40] Zahl-Thanem, A. \& Haugen, M. S. (2019). Attitudes toward immigrants in rural Norway. A rural-urban comparison. Sociologia Ruralis 59(4), 685-700. DOI: 10.1111/soru.12251. 
Other sources

[41] Sandemose, A. (1933). En flyktning krysser sitt spor: fortelling om en morders barndom. Oslo: Tiden. 